\title{
Potential Taurine Content from Three Different Macroalgaes: Halimeda opuntia L., Sargassum sp. and Eucheuma cottonii L.
}

\author{
Ulfa Azzizah $^{1}$ Endang L. Widiastuti1 ${ }^{1,2, *}$ Henni W. Maharani ${ }^{2}$
}

\begin{abstract}
${ }^{I}$ Department of Biology, Universitas Lampung, Bandar Lampung, Indonesia.
${ }^{2}$ Coastal and Marine Research Center, Universitas Lampung, Bandar Lampung, Indonesia

${ }^{*}$ Corresponding author. E-mail:elwidi@yahoo.com
\end{abstract}

\begin{abstract}
As one of the marine resources, macroalgae presumably contains of free amino acid such as taurine. Taurine is known to be one of the most important amino acid related to hyperosmotic stress for most of living organisms. The study was conducted to explore the taurine contain from the most abundance macroalgae found in Indonesia seawater, especially in Lampung Province, namely Halimeda opuntia L., Sargassum sp. and Eucheuma cottonii L. Maceration followed by ethanol extraction was applied to those three different macroalgae and the filtrate was identified for its taurine content by using UV-Vis spectrophotometry. Standard of pure taurine of 0,1 and 1 M (NOW) was used and the maximum wavelength of under the UV-Vis spectrophotometry was $630 \mathrm{~nm}$. Simple correlation from the standard taurine was $\mathrm{y}=0.001 \mathrm{x}+0.033$ and used to determine the taurine content of those three macroalgae. The result indicated that potential taurine content of Halimeda opuntia $\mathrm{L}$ was $7.85 \mathrm{mg} / 100 \mathrm{~g}$ dry mass, Sargassum sp was $1.21 \mathrm{mg} / 100 \mathrm{~g}$ dry mass and Eucheuma cottonii L was $4.61 \mathrm{mg} / 100 \mathrm{~g}$ dry mass.
\end{abstract}

Keywords: Macroalgae, Halimeda opuntia, Sargassum sp, Eucheuma cottonii, taurine

\section{INTRODUCTION}

Indonesia is known as one of the world's megacenter biodiversity including the biodiversityof its marine biota. One of the potential marine biota in Indonesia is macroalgae. In terms of macroalgae productivity is more beneficial because there are no seasonal variations, easier to extract, and abundant raw materials [1]. According to research conducted by Kawasaki et al [2] macroalgae have taurine content. Among the 29 types of macroalgae studied, red macroalgae have relatively high taurine content while green macroalgae and brown macroalgae do not contain taurine. Taurine is one of the stimulant substances that can trigger stamina, so it is widely used in energy supplements. Taurine also plays an important role in maintaining the smoothness of various bodily processes [3] Until now there is very little research on macroalgae potential containing taurine, for this reason the researchers tested the taurine content of ethanol extract Halimeda opuntia L., Sargassum sp. and Eucheuma cottonii L.

\section{METHODS}

\subsection{Place and Time of Research}

The research was conducted in Mei 2019 until June 2019, in the Botanical Laboratory of Biology
Department, Faculty of Mathematics and Natural Sciences, University of Lampung.

\subsection{Tools and Materials}

The tools used in this research are UV-Vis spectrophotometry, oven, rotary evaporator, Erlenmeyer \& beaker glasses, vortex, measuring cup, test tube, test tube rack, buchner funnel, pipette volume, dropper pipette, filter paper, carbon paper, blender, and a stirrer. The materials used are Halimeda opuntia L., Sargassum sp., Eucheuma cottonii L., ethanol96\%, taurine powder (NOW), and aquades.

\subsection{Extraction Process of Macroalgae}

Halimeda opuntia L., Sargassum sp. and Eucheuma cottonii L. used in this study were obtained from Ketapang Beach, Lampung Indonesia. Halimeda opuntia L., Sargassum sp. and Eucheuma cottonii L. were best washed with running water, dried in an oven at $40^{\circ} \mathrm{C}$, and crushed in to powder. As much as 100 grams of powder of each macroalgae was soaked with 1000 $\mathrm{ml}$ of ethanol $96 \%$ and let stand for 48 hours, maserate then was filtered with a Buchner funnel and the obtained filtrate is concentrated using a rotatory evaporator [4]. 


\subsection{Extraction Process of Macroalgae}

\subsubsection{Determination Wavelength Maximum}

The maximum wavelength was determined by the detection of the absorbance value of one standard taurine solution in the wavelength range of 400-800 nm using UV-Vis spectrophotometry. The standard solution of $1 \mathrm{M}$ taurine was determined for its absorbance using UV-Vis spectrophotometry and it was at wavelength of 400-800 nm with distilled water absorption.

\subsubsection{Determination Standard Curve Taurine}

A total of 12.5 grams of taurine powder were added with $10 \mathrm{ml}$ of distilled water, then homogenized using vortex until it dissolved completely. After that 20 dilutions were carried out so that the concentration of standard solution of taurine $0.1 \mathrm{M}$ and $1 \mathrm{M}$ was obtained. Each standard solution was measured for absorbance at the maximum wavelength, then a calibration curve was made for the relationship between taurine (M) concentration and absorbance value.

\subsubsection{Determination of Total Taurine Level}

1 gram of ethanol extract of Halimeda opuntia L., Sargassum sp. and Eucheuma cottonii L. were dissolved in $10 \mathrm{ml}$ of distilledwater. Absorbance of each solution of macroalgae ethanol extract was measured by UV-Vis spectrophotometry at maximum wavelength. Repeated 3 times.

\subsection{Data Analysis}

The data obtained were analyzed quantitatively and presented in the form of data tabulation. The primary data obtained from the absorbance value of the taurine as comparative solution used as a standard curve so that a linear regression equation was obtained $\mathrm{y}=\mathrm{ax}+\mathrm{b}$. Total levels of taurine in Halimeda opuntia L., Sargassum sp. and Eucheuma cottonii L.samples were calculated by entering each absorbance value into linear regression equations and the results were expressed in $\mathrm{mg}$ units in gram extract of macroalgae.

\section{RESULTS AND DISCUSSION}

\subsection{Determination of Maximum Wavelength}

The results of determining the maximum wavelength of a standard solution of $1 \mathrm{M}$ taurine in the wavelength range of $400-800 \mathrm{~nm}$ (Figure 1).

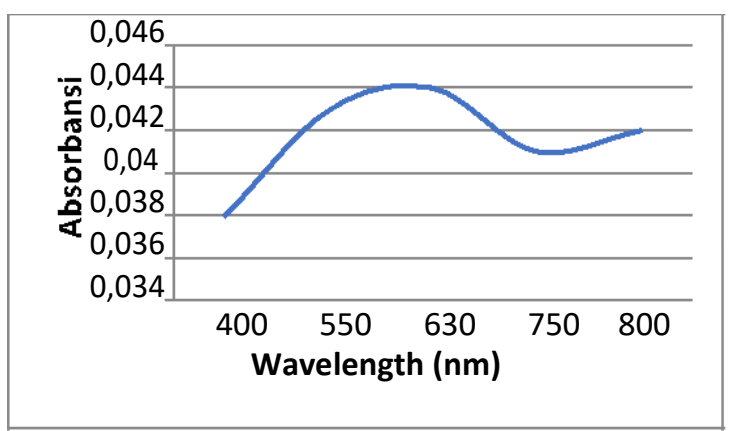

Figure 1 The maximum wavelength of taurine solution

The purpose of determining the maximum wavelength was to determine the taurine wavelength that is able to provide maximum absorption so that it can be absorbed by UV-Vis spectrophotometry. Obtained wavelength measurement results with 3 times the control at maximum absorption 0.044 with a wavelength of $630 \mathrm{~nm}$. In accordance with the literature which states that Taurine has a maximum wavelength of $630 \mathrm{~nm}$ [5].

\subsection{Taurine Standard curve and linearity test}

The concentration used in the standard curve of curricula is $0.1 \mathrm{M}$ and $1 \mathrm{M}$ with a maximum wavelength of $630 \mathrm{~nm}$. Standard curve taurine can be seen in Figure 2.

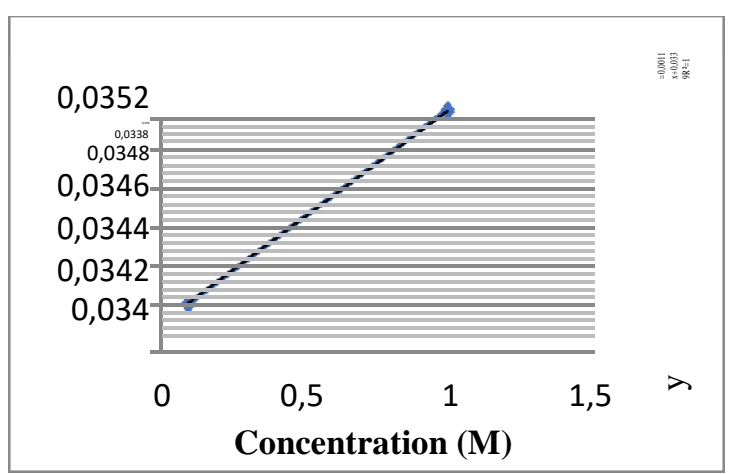

Figure 2 Taurine standard curve

Taurine standard curve was applied by making taurine solution with the concentration of $0.1 \mathrm{M}$ and $1 \mathrm{M}$. Based on the result obtained in Figure 2, the standard solution of taurine $0.1 \mathrm{M}$ had an average absorbance of 0.034 while the standard solution of taurine $1 \mathrm{M}$ had an average absorbance of 0.035 , this shows that the absorbance value produced increase parallel to the increase in taurine concentration. This was also in accordance with the Lambert-Beer law where $A=a b c$, i.e. the absorbance value (A) is directly proportional to the concentration value (c) [6]. 
From the taurine standard curve obtained a linear regression equation between concentration and absorbance, namely $\mathrm{y}=0.001 \mathrm{x}+0.033$ with the value of correlation coefficient that is $\mathrm{r}=1$. Based on the results obtained the correlation coefficient value obtained has met the requirements of AOAC [7] which is close to or equal to 1.

\subsection{Linearity test}

The resulting linear regression equation then was used to determine taurine concentrations in ethanolic extraction of Halimeda opuntia L., Sargassum sp. and Eucheuma cottonii L. by entering the absorption value into the regression equation of $y=0.001 x+0.033$. The standard curve was the relationship between the absorbance value of concentration.

The standard curve produced could be used for linearity testing. The purpose of the linearity test was to prove the existence of a linear relationship between the concentration of the substance and the response of the tool. Linearity was usually expressed in correlation coefficient (r).

Then the regression equation obtained $y=a+b x$ $y=0.001 x+0.033$. Correlation coefficient ( $r$ ) equal to 1 from the standard curve shows a correlation between concentration and absorbance. If the number of correlation coefficient ( $r$ ) is equal to 1 , then the two variables have a perfectly positive linear relationship.

Table 1. The linearity test results of taurine standard solutions

\begin{tabular}{|c|c|c|c|}
\hline $\begin{array}{c}\text { Concentration } \\
(\mathbf{M})\end{array}$ & Replication & Absorbance & Average \\
\hline 0.1 & 1 & 0.034 & \\
& 3 & 0.034 & 0.034 \\
1 & 1 & 0.034 & \\
\hline & 2 & 0.035 & 0.035 \\
\hline $\begin{array}{c}\text { Slope (b) } \\
\text { Intercept axis } \\
\text { (a) }\end{array}$ & 3 & 0.035 & \\
\hline $\begin{array}{c}\text { Correlation } \\
\text { coefficient (r) }\end{array}$ & & 0.033 & \\
\hline
\end{tabular}

\subsection{Determination of Possible Taurine Concentration on Macroalgae extract}

Table 2. Taurine concentration in ethanol extraction of macroalgae

\begin{tabular}{|l|c|c|c|c|c|}
\hline \multicolumn{1}{|c|}{ Sample } & Absorbance & $\begin{array}{c}\text { Average } \\
\text { Absorbance }\end{array}$ & $\begin{array}{c}\text { Total } \\
\text { Levels } \\
(\mathbf{m g} / \mathbf{1 0 0 g})\end{array}$ & $\begin{array}{c}\text { Average } \\
\text { Levels } \\
(\mathbf{m g} / \mathbf{1 0 0 g})\end{array}$ & $\begin{array}{c}\text { Total } \\
\text { Level } \\
(\mathbf{m M})\end{array}$ \\
\hline H. Opuntia L & 0.798 & 0.818 & 8.00 & 7.85 & 6.20 \\
& 0.833 & & 7.90 & & \\
\hline & 0.823 & & 1.21 & & \\
Sargassum sp & 0.154 & 0.154 & 1.21 & 1.21 & 0.96 \\
& 0.154 & & 1.21 & & \\
E. cottonii L & 0.493 & & 4.60 & & 3.60 \\
& 0.500 & 0.495 & 4.67 & 4.61 & \\
\hline
\end{tabular}

\subsection{Discussion}

Ethanol extract of Halimeda opuntia L. had average absorbance of 0.818 with potential taurine concentration of the sample was $7.85 \mathrm{mg} / 100 \mathrm{~g}$ dry mass. While ethanol extract of Sargassum sp. obtained the average absorbance of 0.154 with potential total taurine concentration was 1.21 $\mathrm{mg} / 100 \mathrm{~g}$ dry mass. While the ethanol extract of Eucheuma cottonii L. obtained the average absorbance of 4.950 with potential total taurine content in the sample of $4.62 \mathrm{mg} / 100 \mathrm{~g}$ dry mass.
In this study, all of ethanol extract of macroalgae indicated possibly to contain natural taurine. Based on the results, Halimeda opuntia L. had the highest taurine content compared to other two macroalgae, namely Sargassum sp and Eucheuma cottonii L. This high content of taurinein Halimeda presumably due to several factors, ecologically, physiologically and histology of Halimeda.

Halimeda opuntia L. grows in shallow waters, specifically in the internal zone with sea water fluctuates following tides. It can experience two tides and twice low tide with almost the same height 
that occurs regularly. The average tidal period is 12 hours 24 minutes. During low tide, Halimeda opuntia L. suffered from dry and easily exposed to ultraviolet radiation, on the contrary, during high tide Halimeda opuntia L. submerged in sea water with varying salinity levels. This extreme environmental condition allows Halimeda opuntia L. to adapt by producing secondary metabolites, one of which in the form of taurine. Taurine plays an important role as one of organic osmolytes compound in macroalgae.

According to Strange and Jackson [8] taurine is an organic osmolyte compound from amino acid derivatives containing sulphur hydryl groups which serves to protect cells from a changing environment. Organic osmolytes are found in high concentrations of around $10 \mathrm{mM}$ to $100 \mathrm{mM}$ in the cytosol of all organisms from low to high levels, from bacteria to humans.

Taurine also acts as an osmoprotective in osmoregulation so that the distribution of energy replaced by taurine can be used for growth [9]. The increasing in extracellular osmolarity will be balanced by an increase in intracellular organic osmolyte in response to compensate for changes in environmental conditions. The bulging of cells will result in the entry of organic osmolytes from the outside which largely due to an active increase in osmolyte transport [9]. Cells that experience osmotic stress generally will accumulate more taurine as a compatible osmolyte compound [9].

Based on the other study related to histology of those three macroalgae indicated that they had different structures [10,11,12,13]. Sargassum sp. and Eucheuma cottonii L. cells had almost similar cell shapes, namely oval round with small diameter sizes and coinciding. Whereas in Halimeda opuntia L. cells were polygonal [11] with large cell diameter sizes.

On the surface of Halimeda opuntia L. cells there was high enough calcium content in the form of calcium carbonate. Calcium carbonate $(\mathrm{CaCo} 3)$ came from metabolic results, deposited in thallus cell tissues, in the form of aragonite and calcite [11]. Aragonite was a mineral from calcium carbonate that was formed at low temperatures [11].

The cell number in macroalgae is influenced by salinity [14]. Water quality parameters that greatly influence the development and growth of macroalgae was salinity, this was directly related to osmoregulation that occurs in cells $[15,16,17]$. Presumably taurine was also accumulated in this action.
Adaptation success will determine the sustainability of organisms in shallow waters [18]. Therefore, Halimeda opuntia that survived in the intertidal zone could accumulate more taurine as osmolyte compound to overcome the changing variations in the environment.

Meanwhile, some study indicated that taurine could be correlated with chlorophyll a [19]. Chlorophyta is the largest group of algal vegetation containing chlorophyll a [20]. In the chloroplast assimilation occurs wherein photosynthetic reducing agents together with ATP played a role in absorbing sulphur compounds [21]. This was related to the synthesis of taurine which requires sulphur, the sulphur is absorbed in the form of sulphate ions for the formation of PAPS-AS (adenosine-3'-phosphate5'-phosphosulfate). The study also indicated that taurine synthesis in algae occur via the serine/sulphate pathway. This pathway used organic sulphate in the L-serine carbon backbone. L-serine was converted to 2aminoacrylate by the enzyme L-serine dehydratase, then converted to cysteate by PAPS-AS (adenosine-3'-phosphate-5'-phosphosulfate).

Cysteate then would be decarboxylated with the help of CSAD/GAD enzyme to taurine [20].

\section{CONCLUSION}

The result indicated that potential taurine content of Halimeda opuntia L was $7.85 \mathrm{mg} / 100 \mathrm{~g}$ dry mass, which much higher compared to Sargassum sp (1.21 mg/100g dry mass) and Eucheuma cottonii L. (4.61 mg/100g dry mass).

\section{REFERENCES}

[1] Waryno, T. Biogeografi Alga Makro (Rumput) Laut di Kawasan Pesisir Indonesia. Kumpulan Makalah Periode 1987-2008. 2008.

[2] Kawasaki, A., A. Ono., S. Mizuta., M. Kamiya., T. Takenaga., S. Murakami. The Taurine Content of Japanese Seaweed. Taurin 20, Advances in Experimental Medicine andBiology 975. 2017.

[3] Militante, J.D., Lombardini, J.B. Taurine: evidence of phsyological function in the retina. J. Nutrition Neurosci. 5 (2). 2002. Pp 75-90.

[4] Indriani, M. Ekstraksi Rumput Laut Cokelat Sargassum sp. (cp 02) dan Pengujian Ekstraksebagai Inhibitor Tirosinase (Tesis). Institut pertanian bogor. Bogor. 2014. 
[5] Lau, Oi-Wah., Lukt, Shiu-Fai, dan Chiu, Teresa P.Y. Spectrophotometric determination of taurine in food samples with phenol and sodium hypochlorite as reagents and ion-exchanges clean-up. Department of Chemistry, Chinese University of Hongkong, Shatin, N.T., Hong Kong. 1990. p. 115.

[6] Day, R.A., Underwood, A. Analisis Kimia Kuantitatif, Edisi Ke-6. 2002. Erlangga. Jakarta.

[7] Association of Analytical Commubities. AOAC Guidelines for Single Laboratory Validation of Chemical Methods for Dietary Suplement and Botanicals. 2002.

[8] Strange, K., dan P.S. Jackson. Swelling Activated Organic Osmolyte Effucks : A New Role for Anion Channel. Kidney InternationalVol. 48. 1997. The International Society of Nephrology. Massachussets. USA.

[9] Pamungkas, W. Pemberian senyawa osmolit organik taurin pada pakan buatan terhadap respon pertumbuhan cobia di BBPBL Lampung. Digital Repository Unila. 2016.

[10] Kadi, A. Cara Mengenal Jenis-jenis dari Makroalga Halimeda. Oseana, Volume XII, No.1. 1987. Pp. 1-12.1

[11] Kadi, A. Karakteristik Makro Algae Berzat Kapur di Perairan Tanjung Sira LombokBarat. Pusat Penelitian Oseanografi LIPI. 2015. Jakarta.

[12] Triastinurmiatiningsih., Ismant., Ertina. Variasi Morfologi dan Anatomi Sargassum sp. di Pantai Bayah Banten. Ekologia, Vol.11 No. 2. 2011. pp 1-10.

[13] Darmawati. Analisa Histology Sel Euchema cottonii pada kedalaman berbeda. OctopusJurnal Ilmu Perikanan, Vol.3 No.1. 2014.
[14] Erich, S.K. and G. Pierre. Micro environmental control on biomineralization: superficial processes of apatite and calcite precipitation in Quaternary soil Reussillon, France. Sedimentology. 46(3). 1999. pp. 463476.

[15] Arisandi, A., Marsoedi., H. Nursyam, dan A. Sartimbul. Pengaruh salinitas yang berbeda terhadap morfologi, ukuran dan jumlah sel pertumbuhan serta rendemen keraginan Kappaphycus alvarezi. Jurnal ilmu kelautan.16 (3). 2011. Pp.143-150.

[16] Choi, T.S., E.J. Kang., J.H. Kim, dan K.Y. Kim. Effects of salinity on growth and nutrient uptake of Ulva pertusa (Chlorophyta) from an eelgrass bed. Algae, 25 (1). 2010. pp. 17-25.

[17] Marwita, R.S.P. Efek sinergis taurin lintah laut (Discodoris sp.) dan temulawak (Curcuma xanthorriza Roxb.) dalam serbuk minuman fungsional. Skripsi. Institut Pertanian Bogor. Bogor. 2013.

[18] Tjitrosoepomo, G. Taksonomi Tumbuhan: Schizophyta, Thallophyta, Bryophyta, Pterydophyta. Gadjah Mada University Press. Yogyakarta. 2011.

[19] Kevin, J. Flynn., Kenneth, J. Jones., Robin, Raine., Jacolyn, Richard., Krystyna, Flynn. Use of intracellular amino acid analysis as an indicator of the physiological status of natural dinoflagellate populations, Mar. Ecol. Prog. Ser. 103, 1994. Pp. 175-186.

[20] Tevatia, R., Allen, J., Rudrappa, D., White, D., Clemente, T.E., Cerutti, H., Demirel, Y., and Blum, P.H. The Taurine Biosynthetic Pathway of Microalgae. Algae Research 9. 2015. p: 2126.

[21] Melis, A., Chen, H.C. Chloroplast sulphate transport in green algae-genes, protein and effects. Photosynth. Res 86(3). 2005. Pp. 299-307. 